\title{
A Protein Associated with Axon Growth, GAP-43, Is Widely Distributed and Developmentally Regulated in Rat CNS
}

\author{
Richard D. Jacobson, Ildikó Virág, and J. H. Pate Skene \\ Department of Neurobiology, Stanford University, Stanford, California 94305
}

\begin{abstract}
Development or regeneration of axons in several systems is accompanied by 20 -100-fold increases in the synthesis of an acidic, axonally transported membrane protein with an apparent molecular weight of 43-50,000 (Benowitz and Lewis, 1983; Skene and Willard, 1981a, b), which we designate GAP-43. We have proposed that some step(s) in axon growth require production of GAP-43, and perhaps a small number of other "growth-associated proteins," at rates much higher than those typical of mature neurons. This hypothesis predicts that virtually all neurons synthesize GAP-43 at elevated levels during normal CNS development. Here we show that a protein similar to GAP-43 from regenerating toad nerves is prominent among the newly synthesized ( ${ }^{35} S$-methionine-labeled) and total (Coomassie bluestained) proteins in neonatal rat cerebral cortex and cerebellum, suggesting that synthesis of GAP-43 is indeed a common feature of many developing neurons. Synthesis and accumulation of the protein decline an order of magnitude as animals mature. Antibodies raised against the rat cortex GAP-43 also recognize electrophoretically similar proteins from regenerating toad optic nerves and from developing hamster sensorimotor cortex, indicating that structural features of GAP-43 are conserved in evolution. Cell-free translation of polyadenylated RNA from neonatal and adult cortex suggests that developmental regulation of GAP-43 synthesis is mediated largely through changes in mRNA abundance. These observations together suggest that developmental regulation of GAP -43 gene expression may be common to most vertebrate $C N S$ neurons.

GAP-43 remains detectable at a low level in adult rat cortex, and it co-migrates on two-dimensional gels with B-50, a synaptic membrane protein which is a preferred substrate for protein kinase $C$ in adult brains. Phosphorylation of the protein by endogenous kinase(s) in vitro is 4-7-fold greater in growth cone membranes than in mature synaptic membranes, which raises the possibility that local modification of the protein in axon terminals may be synergistic with regulation of GAP-43 synthesis in the cell body.
\end{abstract}

Elongation of axons is a fundamental process in nervous system development and in the regeneration of injured pathways. Although some important en vironmental influences on axon growth have been demonstrated (e.g., Benfey and Aguayo, 1982; Fallon, 1985; LeTourneau, 1975; Richardson et al., 1984; Rogers et al.,

\footnotetext{
Received Oct. 2, 1985; revised Dec. 20, 1985; accepted Dec, 26, 1985.

We thank Mark Willard and Karina Meiri for advice on electrophoretic transfer of GAP-43 and on antibody preparation, Jim Spudich for the use of his scanning densitometer, and Stuart Feinstein, Elly Nedivi, Guriqbal Basi, and Michael LaBate for comments on the manuscript. This work was supported by NIH Grant NS 20178 and the Isabelle Niemala Fund. R.D.J. is a recipient of an NRSA postdoctoral fellowship, and J.H.P.S. is a recipient of fellowships from the Alfred P. Sloan Foundation and the Searle Scholars Program.

Correspondence should be addressed to Pate Skene, Department of Neurobiology, Stanford University, Stanford, CA 94305.

Copyright (c) 1986 Society for Neuroscience $0270-6474 / 86 / 061843-13 \$ 02.00 / 0$
}

1985; Sanes, 1985), the critical molecular events within the neuron that regulate axon growth have scarcely begun to be elucidated. We suspect that, by analogy with the regulation of cell growth in non-neural systems (e.g., Bishop, 1985; Weinberg, 1985), a few axonal macromolecules might be key sites for the control of axon growth. It is upon these intraneuronal regulatory molecules that environmental elements must exert their influences.

Among the candidate molecules for regulation of axon growth are the "growth-associated proteins" (GAPs) whose synthesis increases one to two orders of magnitude during successful axon regeneration in several systems (Benowitz et al., 1981; Benowitz and Lewis, 1983; Heacock and Agranoff, 1982; Skene and Willard, $1981 \mathrm{a}, \mathrm{b})$. We have proposed that the individual growthassociated proteins are essential participants in some aspects of axon growth, and that neurons in the mammalian CNS that fail to regenerate their axons do not synthesize GAPs in sufficient abundance to support axon growth (Skene and Willard, 1981b). If GAPs are essential for axon growth, one would expect that virtually all neurons would synthesize substantial levels of GAPs during normal developmental axon outgrowth. Thus, at times when many neurons are extending axons, one would expect GAP synthesis to be a prominent feature of developing brains. Conversely, if most neurons in the mature mammalian CNS fail to synthesize GAPs at a level sufficient to sustain axon growth, one would expect that GAP synthesis would be much lower in mature brain. Here we show that both of these predictions are fulfilled for one "growth-associated protein," GAP-43.

\section{Materials and Methods}

Materials
ss-methionine (approximately $1000-1400 \mathrm{Ci} / \mathrm{mmol}$ ) was obtained from
Amersham. Urea, sucrose, SDS, acrylamide, and bisacrylamide were Amersham. Urea, sucrose

\section{Labeling of rat brain proteins in vivo}

Sprague-Dawley rats were obtained from Simonsen. The age of the rats used ranged from immediately postnatal $(0 \mathrm{~d})$ to adult. The rats were anesthetized by cold $(0-14 \mathrm{~d})$ or by ketamine $(100-150 \mathrm{mg} / \mathrm{kg}$, i.p.). The calvarium was surgically exposed, and $20-100 \mu \mathrm{Ci}$ of ${ }^{35} S$-methionine was injected intracerebrally with a Hamilton syringe, either through a hole drilled in the skull or directly through the skull. After 3-5 hr survival, the animals were killed with $\mathrm{CO}_{2}$, and their brains quickly removed and stored at $-70^{\circ} \mathrm{C}$.

\section{Labeling of GAP-43 in regenerating toad nerves}

Toads (Bufo marinus; Delta Biologicals, Vidalia, LA) were anesthetized on ice, and the left optic nerve crushed with forceps approximately 2$3 \mathrm{~mm}$ proximal to the optic chiasm. Two weeks later, ${ }^{35} S$-methionine was injected into the left eye. The toads were killed $12 \mathrm{hr}$ after injection, and the portion of the optic nerve and optic tract distal to the crush site removed. The nerves were homogenized and particulate fractions prepared for electrophoresis, as described for rat brains. 


\section{Tissue preparation and electrophoresis}

The cerebral hemispheres or cerebellum were homogenized with 15 passes of a Teflon pestle in $\mathrm{H}$ buffer containing $10 \mathrm{~mm}$ Tris, $\mathrm{pH} \mathrm{7.5,5}$ mM EDTA, and $5 \mathrm{~mm}$ dithiothreitol (DTT). Soluble and particulate fractions of this homogenate were separated by centrifugation at $100,000 \times g$ for $30 \mathrm{~min}$. The pellet from this centrifugation was resuspended in a solubilizing buffer consisting of $0.5-1.0 \%$ SDS and $5 \mathrm{~mm}$ DTT, and incubated at $95^{\circ} \mathrm{C}$ for $5 \mathrm{~min}$. Protein was determined by the method of Lowry et al. (1951), using BSA as a standard, and radioactivity was determined by trichloroacetic acid (TCA) precipitation on glass filters and subsequent liquid scintillation counting. The samples were then diluted $1: 1$ with a second solution containing $8 \mathrm{~m}$ urea, $5 \mathrm{~mm}$ DTT, and $10 \%$ nonidet P-40. Proteins from the soluble fraction were precipitated by addition of 0.5 volume of $21 \%$ TCA and centrifugation at $8000 \times g$ for $15 \mathrm{~min}$. The TCA pellet was washed twice with diethyl ether, dried thoroughly, and solubilized as described for the particulate fraction above.

Two-dimensional electrophoresis was carried out essentially according to the method of O'Farrell (1975). Isoelectric focusing was performed using tube gels (1.2 mm diameter) containing $4 \%$ acrylamide, $0.21 \%$ bisacrylamide, $9 \mathrm{M}$ urea, and $2.4 \%$ ampholytes. The specific ampholytes employed were at $\mathrm{pH} 3.5-10$ and either $\mathrm{pH} 5-7$ or $\mathrm{pH} 4-6$, at a ratio of $2: 1$. After focusing at $350-400 \mathrm{~V}$ for $18-22 \mathrm{hr}$, the tubes were overlaid on an SDS-acrylamide slab gel and electrophoresed in the buffer system of Laemmli (1970). The slab gels consisted of either a uniform acrylamide concentration (usually $12 \%$ ), or a 5-15\% linear gradient poured with a Beckman density gradient former.

After completion of the second dimension, gels were fixed and stained with Coomassie brilliant blue according to the method of Fairbanks et al. (1971) and then impregnated with xylenes and 2,2-diphenyloxazole using the APEX system of Jen and Thach (1982). After drying on filter paper, the gels were exposed at $-70^{\circ} \mathrm{C}$ to Kodak XAR x-ray film that had been previously flashed to an O.D. of 0.1 (Laskey and Mills, 1975). The exposures were adjusted to approximately equalize the product of the total radioactivity loaded on the gel times the length of the exposure, expressed as CPM-days, among gels that were to be compared. The optical density of individual protein spots was determined using a scanning densitometer (Transidyne General Corp.).

\section{Purification of rat brain RNA}

Total RNA from rat brains was obtained by the method of Chirgwin et al. (1979). Brain tissue was homogenized in 9 volumes of $6 \mathrm{M}$ guanidine thiocyanate, $0.5 \%$ sodium $N$-lauryl sarcosinate, $0.5 \% p$-mercaptoethanol, and $50 \mathrm{~mm} \mathrm{Na-citrate,} \mathrm{pH}$ 7.0. Cell debris was removed by centrifugation at $5000 \times g$ for $10 \mathrm{~min}$, and the supernatant was layered onto a solution of $5.7 \mathrm{M}$ cesium chloride and $100 \mathrm{~mm}$ EDTA. RNA was pelleted by centrifugation at $120,000 \times g$ for $16 \mathrm{hr}$, redissolved in $6 \mathrm{M}$ guanidine $/ 25 \mathrm{~mm}$ EDTA, and precipitated by addition of $10 \%$ volume $3 \mathrm{~m}$ sodium acetate and 2 volumes ethanol. The ethanol precipitate was collected after incubation at $-20^{\circ} \mathrm{C}$ by centrifugation, washed with $70 \%$ ethanol, and dried under $\mathrm{N}_{2}$.

Poly-A ${ }^{+}$RNA was purified from the total RNA preparation by oligodT chromatography (Aviv and Leder, 1972). RNA was translated in vitro using a commercial wheat germ system (BRL wheat germ IVT system, nuclease-treated) according to the manufacturer's protocol; ${ }^{35} S$ methionine was the labeled amino acid used for translation. Translation products were recovered by TCA precipitation and solubilized for 2-D electrophoresis, as described above.

\section{Phosphorylation of GAP-43}

Growth cone particles were isolated from 3-d-old rat brains by the method of Pfenninger et al. (1983); synaptosomes from adult rat brain were isolated according to Cohen et al. (1977) and Ueda et al. (1979). Samples from the discontinuous sucrose gradients were diluted 1:1 with lysis buffer containing $1 \mathrm{~mm} N$-tris(hydroxymethyl)methyl-2-aminoethanesulfonate (TES), $\mathrm{pH} 7.3 ; 1 \mathrm{~mm} \mathrm{MgCl}_{2}$; and $0.5 \mathrm{~mm} \mathrm{CaCl}$. After stirring $15 \mathrm{~min}$ on ice, the lysed samples were centrifuged $30 \mathrm{~min}$ at $100,000 \times g$. The pelleted membranes were resuspended in lysis buffer. Aliquots of the resuspended membranes were assayed for total protein according to Lowry et al. (1951), using BSA as a protein standard.

Aliquots of growth cone or synaptosomal membranes containing 15 $\mu \mathrm{g}$ total protein were incubated in a reaction mixture containing $50 \mathrm{~mm}$ sodium acetate, $10 \mathrm{~mm}$ magnesium acetate, and $1 \mathrm{~mm}$ calcium chloride, pH 6.5. ${ }^{32} P$-ATP was added to a final concentration of $10 \mu \mathrm{M}$ containing
$1 \mu \mathrm{Ci}^{32} \mathrm{P}$ in a final reaction volume of $25 \mu$ l. Reaction mixtures were incubated $3 \mathrm{~min}$ at $30^{\circ} \mathrm{C}$, and the reactions terminated by addition of $25 \mu \mathrm{l}$ of $2 \% \mathrm{SDS} / 2.5 \mathrm{~mm}$ EDTA. Aliquots of each reaction mix were analyzed by one- and two-dimensional electrophoresis, and labeled proteins were detected by exposure to $x$-ray film.

\section{Preparation of antibodies}

GAP-43 was purified in denatured form from brains of rats $7-13 \mathrm{~d}$ of age. Brains were homogenized in $\mathrm{H}$ buffer $(10 \mathrm{ml} / \mathrm{gm}$ wet weight) and a crude particulate fraction collected by centrifugation at $100,000 \times g$ for $30 \mathrm{~min}$. The pellets were dissolved in $1 \%$ SDS and aliquots removed and assayed for total protein. To the remainder of the sample, we added an equal volume of $10 \%$ nonidet P-40/8 $\mathrm{m}$ urea $/ 5 \mathrm{~mm}$ DTT. Aliquots containing approximately $0.5 \mathrm{mg}$ total protein were applied to each of 12 isoelectric focusing (IEF) gels prepared as for analytical 2-D gels, except that the preparative gels were poured in $0.5-\mathrm{cm}$-diameter tubes. Isoelectric focusing was carried out as described above, and one tube was removed and stained according to Malik and Berrie (1972). We aligned the remaining gels with the stained gel and cut out $0.5 \mathrm{~cm}$ segments corresponding to the position of GAP-43. These gel segments were minced, incubated for $1 \mathrm{hr}$ with transfer buffer, and loaded onto a preparative SDS-polyacrylamide gel $(10 \%$ polyacrylamide in a $1-\mathrm{cm}$ diameter tube). Electrophoresis was carried out and proteins eluted in the preparative electrophoresis chamber obtained from BRL, and $1 \mathrm{ml}$ fractions were collected. Aliquots of each fraction were analyzed by analytical SDS-PAGE and detected by silver staining according to Morrisey (1981). Fractions containing a single band with a molecular weight appropriate for GAP-43 were pooled and analyzed by 2-D electrophoresis. The pooled GAP- 43 fractions were dialyzed against $0.05 \%$ SDS and concentrated approximately 5 -fold by vacuum centrifugation.

Approximately $200 \mu \mathrm{g}$ of GAP-43 was emulsified in an equal volume of Freund's complete adjuvant, with the addition of $1 \mathrm{M} \mathrm{NaCl}$ as needed to promote emulsification (approximately $100 \mathrm{~mm}$ final concentration), and the emulsion injected into a rabbit subcutaneously at multiple sites. Three boosts of approximately $50 \mu \mathrm{g}$ GAP-43 in incomplete Freund's adjuvant were made at 1 month intervals, and serum was collected 1 week after each boost.

For affinity purification of antibodies, $100 \mu \mathrm{g}$ of GAP-43 was incubated overnight with $\mathrm{CNBr}$-activated agarose beads (Sigma), according to Parikh et al. (1974). Serum was passed twice through a column of the GAP-43-containing bcads, and the flow-through collected. The column was then washed with 10 volumes of $50 \mathrm{~mm}$ Tris, $200 \mathrm{~mm} \mathrm{NaCl}$, $\mathrm{pH} 7.5$ (TBS) and the bound antibodies eluted with $0.2 \mathrm{M}$ glycine, $\mathrm{pH}$ $2.4 ; 0.5 \mathrm{ml}$ fractions were collected into tubes containing $55 \mu \mathrm{l}$ of $2 \mathrm{M}$

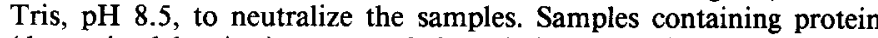
(determined by $A_{280}$ ) were pooled, and these constitute the affinitypurified antibody.

Immunoblotting of GAP-43 requires special conditions (K. Meiri, personal communication). To transfer proteins from SDS-polyacrylamide gels to nitrocellulose for antibody staining, gels were soaked 1$2 \mathrm{hr}$ in $10 \%$ trichloroacetic acid/ $10 \%$ acetic acid $/ 20 \%$ isopropanol, then soaked 1-2 hr in $25 \mathrm{~mm}$ Tris base/192 mM glycine/1\% SDS. Electrophoretic transfer of proteins to nitrocellulose was then carried out for $16 \mathrm{hr}$ at $30-50 \mathrm{~V}$ at $4^{\circ} \mathrm{C}$ in a transfer buffer containing $20 \mathrm{~mm}$ Tris base, $150 \mathrm{~mm}$ glycine, $20 \% \mathrm{mcthanol}$, and $0.05 \%$ SDS. The resulting Western blots were incubated $1 \mathrm{hr}$ with $1 \% \mathrm{BSA}$ in TBS containing $0.05 \%$ nonidet P-40, and then incubated overnight with serum at a dilution of 1:100. After washing the filters in TBS $/ 0.05 \%$ nonidet P- 40 , the bound antibody was detected by sequential incubation with biotinylated goat anti-rabbit IgG and an avidin-biotin complex of HRP. We used 4-chloro-1-naphthol as a chromophore in the peroxidase colorimetric reaction.

\section{Results}

We used 2-D electrophoresis to identify overall differences in protein synthesis between neonatal and adult rat cortex, and to look for GAP-like proteins. One protein in the membrane fraction (washed pellet from a $10^{5} \times \mathrm{g}, 30 \mathrm{~min}$ spin) of neonatal cortex appeared to correspond to the growth-associated protein GAP-43 described in regenerating toad optic nerve (Skene and Willard, 1981a). The rat cortex protein has a pI of about 4.6 and an apparent molecular weight of about $47 \mathrm{kDa}$ on a $12 \%$ polyacrylamide gel, similar to toad GAP-43 (the discrepancy in apparent molecular weight is discussed below). When samples 


\section{Neonatal rat cortex}

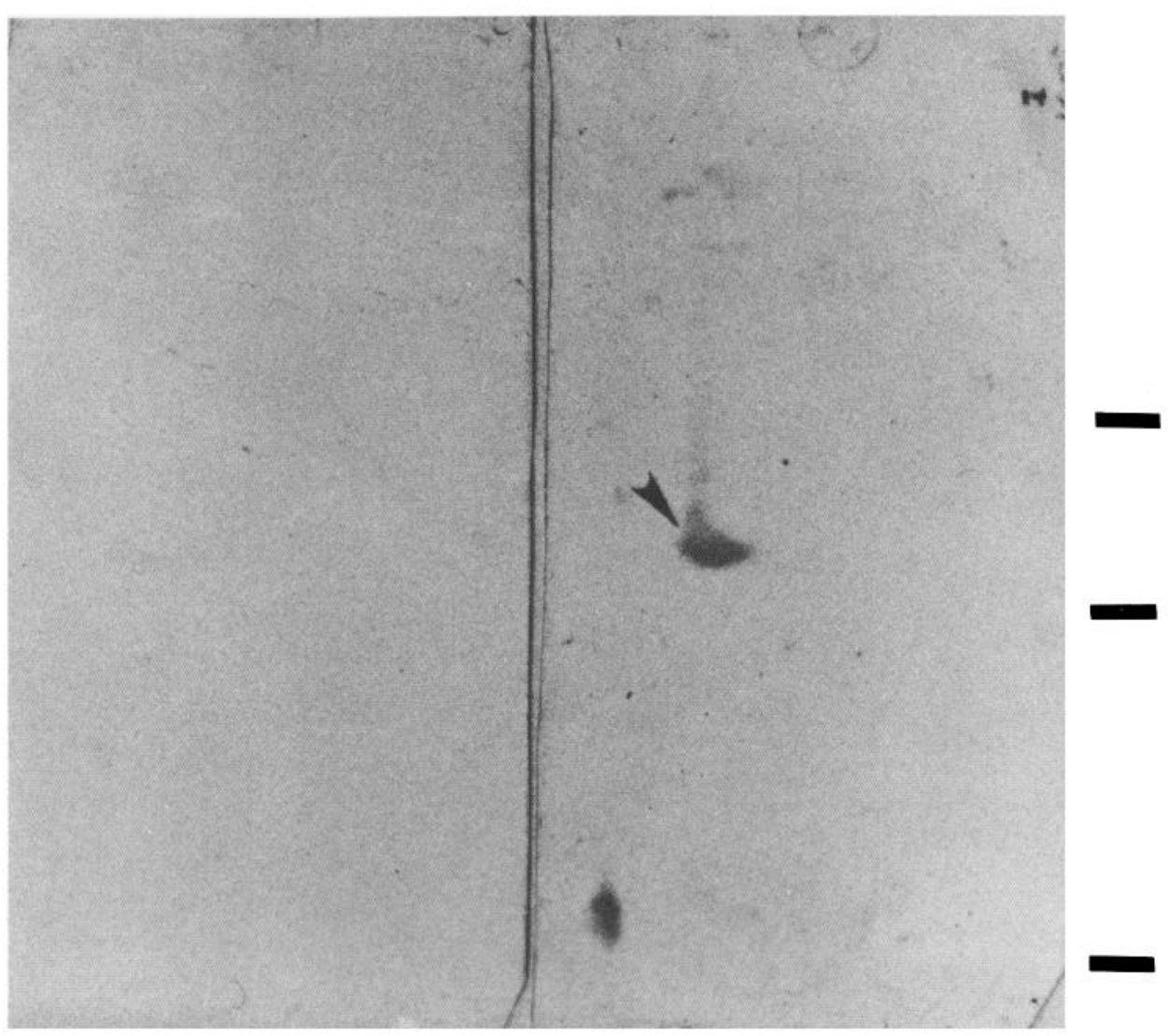

\section{Pre-immune}

\section{Immune}

B

Toad optic $n$. $\begin{array}{llll}N & R & N\end{array}$

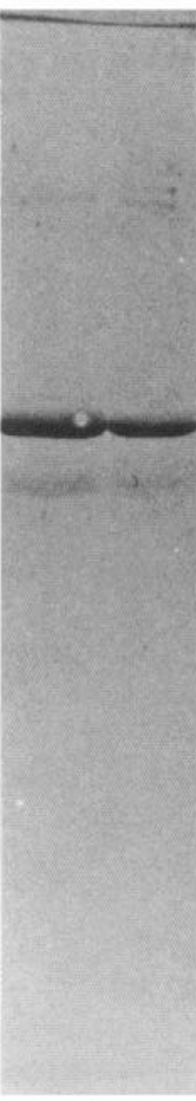

Pre.

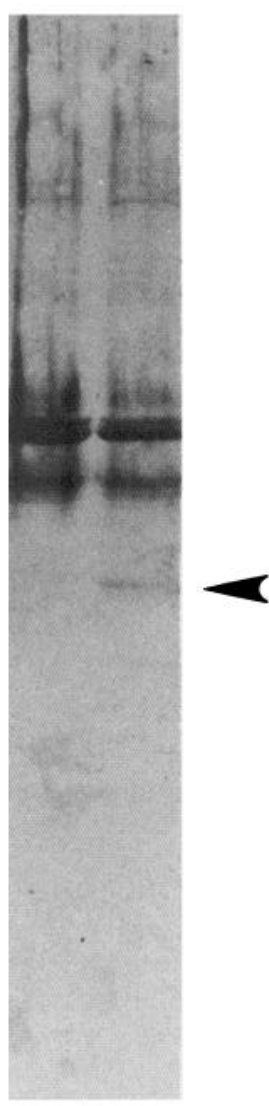

Imm.

Figure 1. Immunologic cross-reactivity of rat and toad GAP-43. A, Immunostaining of Western blots of particulate fractions from 13-d-old rat cortex separated by $2-\mathrm{D}$ electrophoresis (acidic half of gels shown, oriented with the acidic end to the left; the pH 4-6 range was expanded). $B$, Immunostaining of Western blots of particulate fractions from normal toad (Bufo marinus) optic nerves and optic tracts ( $N$ ) and from regenerating nerve/tracts taken $10 \mathrm{~d}$ after optic nerve crush $(R)$, separated on one-dimensional gels. In both $A$ and $B$, the vertical gel dimension is SDS-PAGE on $10 \%$ polyacrylamide gels, and the blots are stained with antiserum raised against purified "GAP-43" from neonatal rat brain (1:100 dilution), or with pre-immune serum from the same rabbit. $A$ confirms that the antiserum shows specific staining for rat "GAP-43"; $B$, shows that the antiserum cross-reacts with toad GAP-43, identified by its apparent molecular weight and induction during optic nerve regeneration (arrow). Coomassie staining of 2-D gels of regenerating toad optic nerves indicates that the samples in $B$ contain much less GAP-43 than the rat samples in $A$, consistent with the lower intensity of immunostaining for the toad samples. Horizontal bars between $A$ and $B$ indicate the positions of molecular-weight markers run on parallel gels, transferred to nitrocellulose and stained with Amido black: BSA, 68,000; ovalbumin, 43,000; and trypsinogen, 25,000 .

of rat cortex and regenerating toad optic nerve were run in the same series of gels, toad GAP-43 and the corresponding protein in rat cortex comigrated on $2-\mathrm{D}$ gels with $12 \%$ polyacrylamide in the second dimension. When higher-resolution gradient gels were used in the second dimension, it was possible to separate the toad and rat proteins by a distance corresponding to a maximum difference in apparent molecular weight of $2 \mathrm{kDa}$. The isoelectric points of the 2 proteins were identical. The rat cortex protein also migrated in a very similar position to the GAP-43 identified in hamster corticospinal tract (Kalil and Skene, in press, data not shown).

To examine further possible homology between toad GAP43 and the rat brain protein, we immunized rabbits with the rat protein purified from neonatal brains by preparative isoelectric focusing and SDS gel electrophoresis. Figure 1 shows that the resulting antiserum recognizes both the neonatal rat brain protein and a protein of nearly identical apparent molecular weight induced during regeneration of toad optic nerves. The antibody also recognizes a protein of similar molecular weight in neonatal hamster somatosensory cortex (see Fig. 9), which is also developmentally regulated (Kalil and Skene, 1986). Cross-reactivity of the anti-rat serum with hamster and toad proteins of similar molecular weights suggests that at least some structural features of the rat brain protein described here are phylogenetically highly conserved.

We found an additional property of this rat cortex protein 


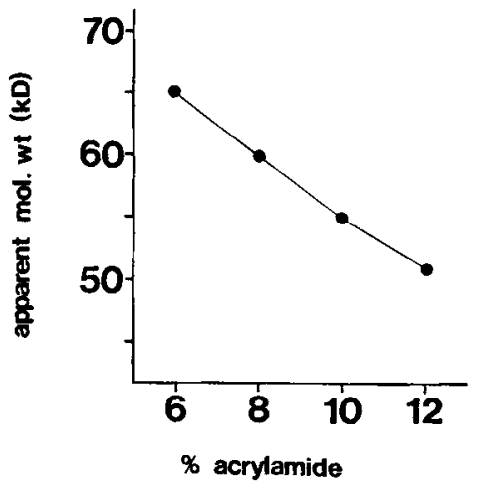

Figure 2. Variation of GAP-43's apparent molecular weight with gel concentration. Labeled $7 \mathrm{~d}$ rat cortex proteins were run on 2-D gels, with the second dimension slab gel consisting of the indicated acrylamide concentration. The gel was stained with Coomassie blue, and the apparent molecular weight of GAP-43 was calculated from the standard curve derived from the migration distances of the molecular-weight standards $(68,43$, and $18 \mathrm{kDa})$.

that was shared with GAP-43 from both toad optic nerve and hamster pyramidal tract; its apparent molecular weight varies inversely with the concentration of acrylamide in SDS gels (Fig. 2). Although similar aberrations in SDS gel migration have been reported for some other proteins (Banker and Cotman, 1972; Segrest and Jackson, 1972), we have observed no other major proteins that exhibit this behavior in our samples. We have used this unusual electrophoretic behavior as an additional empirical criterion for identifying GAP-43-like proteins by comparing the relative mobilities of these proteins on $2-\mathrm{D}$ gels with either $12 \%$ polyacrylamide or a gradient of 5-15\% polyacrylamide in the second dimension. In a 5-15\% gradient, GAP-43 migrates through low acrylamide concentrations during the run and exhibits an apparent molecular weight of $56-60 \mathrm{kDa}$, compared to $46-50 \mathrm{kDa}$ on a $12 \%$ gel (Fig. 3 and Table 1 ). The degree of this apparent molecular-weight shift is similar for GAP-43 and the rat cortex protein.

The electrophoretic similarities between the rat brain protein and toad GAP-43, and the cross-reactivity of the anti-rat antiserum with a protein induced during toad optic nerve regeneration, strongly suggest that the rat protein described here is homologous to toad GAP-43. We will therefore refer to the rat protein as GAP-43.

\section{Distribution and developmental changes of rat GAP-43}

Rat GAP-43, identified on the basis of 2-D gel position and apparent molecular-weight shift, was found in the membrane fractions of neonatal cortex, cerebellum, and superior colliculus. The time course of GAP-43 synthesis and steady-state abundance was studied in detail in both cortex and cerebellum.

The relative amount of GAP-43 synthesized was determined from fluorographs of ${ }^{35} S$-methionine-labeled proteins from various postnatal ages separated by 2-D gel electrophoresis. Labeling of GAP-43 was normalized to total protein synthesis at each age by adjusting exposure of each fluorograph in series of gels so that the product of exposure time and total radioactivity loaded onto the gel was the same for all samples. This permitted us to quantify synthesis of GAP-43, relative to total protein synthesis at each age, by direct comparison of GAP-43 spot intensity on the fluorographs. Figure 4 shows one time series of fluorographs; similar results were obtained with 5 independent analyses. Two series of fluorographs were analyzed by densitometry to quantify relative GAP-43 synthesis as a function of age (Fig. 5). Synthesis of GAP-43 is relatively high in the cortex at birth, and increases about $30-40 \%$ in the first week. There-
Table 1. Estimated apparent molecular weights of GAP-43-like proteins from various sources ${ }^{a}$

\begin{tabular}{lll} 
Sample & $\begin{array}{l}12 \% \text { Gels } \\
(\mathrm{kDa})\end{array}$ & $\begin{array}{l}5-15 \% \\
\begin{array}{l}\text { Gradient } \\
\text { gels (kDa) }\end{array}\end{array}$ \\
\hline Toad optic nerve & $47-48$ & $56-57$ \\
Rat cerebral cortex & $48-51$ & $56-58$ \\
Rat cerebellum & 50 & $58-60$ \\
B-50 (rat) & $47-48$ & $55-59$ \\
Translation product, & & \\
$\quad$ rat cortex poly $\mathrm{A}^{+}$RNA & $48-50$ & $59-60$
\end{tabular}

"The values shown represent the apparent molecular weights calculated independently for each sample, using 2-D electrophoresis with the indicated concentration of acrylamide in the second (SDS) dimension. When the GAP-43like proteins from different sources are compared directly on parallel gels or in mixed samples, all the rat proteins comigrate precisely. Toad GAP-43 precisely comigrates with the rat proteins on $12 \%$ gels and overlaps with them on the gradient gels.

after, the synthesis declines sharply to about $1 / 6$ of the $7 \mathrm{~d}$ level at 2 weeks. Over the next 4 weeks, the level of synthesis declines to the adult level, approximately 20 -fold lower than the $7 \mathrm{~d}$ level. These results were not affected by the presence or absence of protease inhibitors during sample preparation, indicating that our observations reflected real changes in the synthesis of the protein. A similar pattern is seen in the cerebellum over the same time periods, except that maximum relative synthesis of GAP-43 appears to occur at or before the time of birth. GAP43 synthesis, relative to total protein synthesis, is approximately $10 \times$ greater in a newborn rat cerebellum than in adults.

The steady-state abundance, shown by Coomassie staining, of rat GAP-43 also declines with increasing age (Fig. 4). However, the abundance of the protein remains relatively constant for several weeks after GAP-43 synthesis begins to decline, indicating that degradation of GAP-43 in the older animals is slow, with a half-life on the order of weeks.

\section{Developmental changes in translatable GAP-43 $m R N A$}

The decrease in GAP-43 synthesis with maturation could be due to a decrease in the level of specific mRNA, or to a decrease in the translational efficiency of the message, or to some combination of the 2 factors. To try to determine which factor is dominant, we analyzed the labeled products of in vitro translation of rat cortex poly $\mathbf{A}^{+}$RNA in a wheat germ extract, using 2-D electrophoresis. The wheat germ system translated protein products effectively up to about $85 \mathrm{kDa}$. Among the products we found a protein with acidic pI and an apparent molecular weight of about $57 \mathrm{kDa}$ on a $5-15 \%$ gradient gel. The apparent molecular weight of this protein (and no other protein in the translation products) shifted to about $47-50 \mathrm{kDa}$ on a $12 \%$ gel (Fig. 6). We concluded on this basis that this protein is identical with GAP-43 labeled in vivo in rat cortex.

When equal amounts of poly $\mathrm{A}^{+}$RNA from neonatal and adult rat cortex are translated, the relative amounts of GAP-43 are substantially different (Fig. 6). There is significantly less GAP-43 in the products of adult RNA than in those of neonatal RNA. The overall pattern of the in vitro synthesized proteins did not appear to change from neonate to adult, and the changes in other identifiable proteins appeared similar to those seen in in vivo labeled proteins (this was not quantified). The decrease in in vitro GAP-43 synthesis from $10 \mathrm{~d}$ to adult was estimated by densitometry to be about 10 -fold. Since the translation conditions were identical and excluded any brain-specific factors that might have influenced translational efficiency, we conclude that this decrease represented an actual decrease in the abun- 

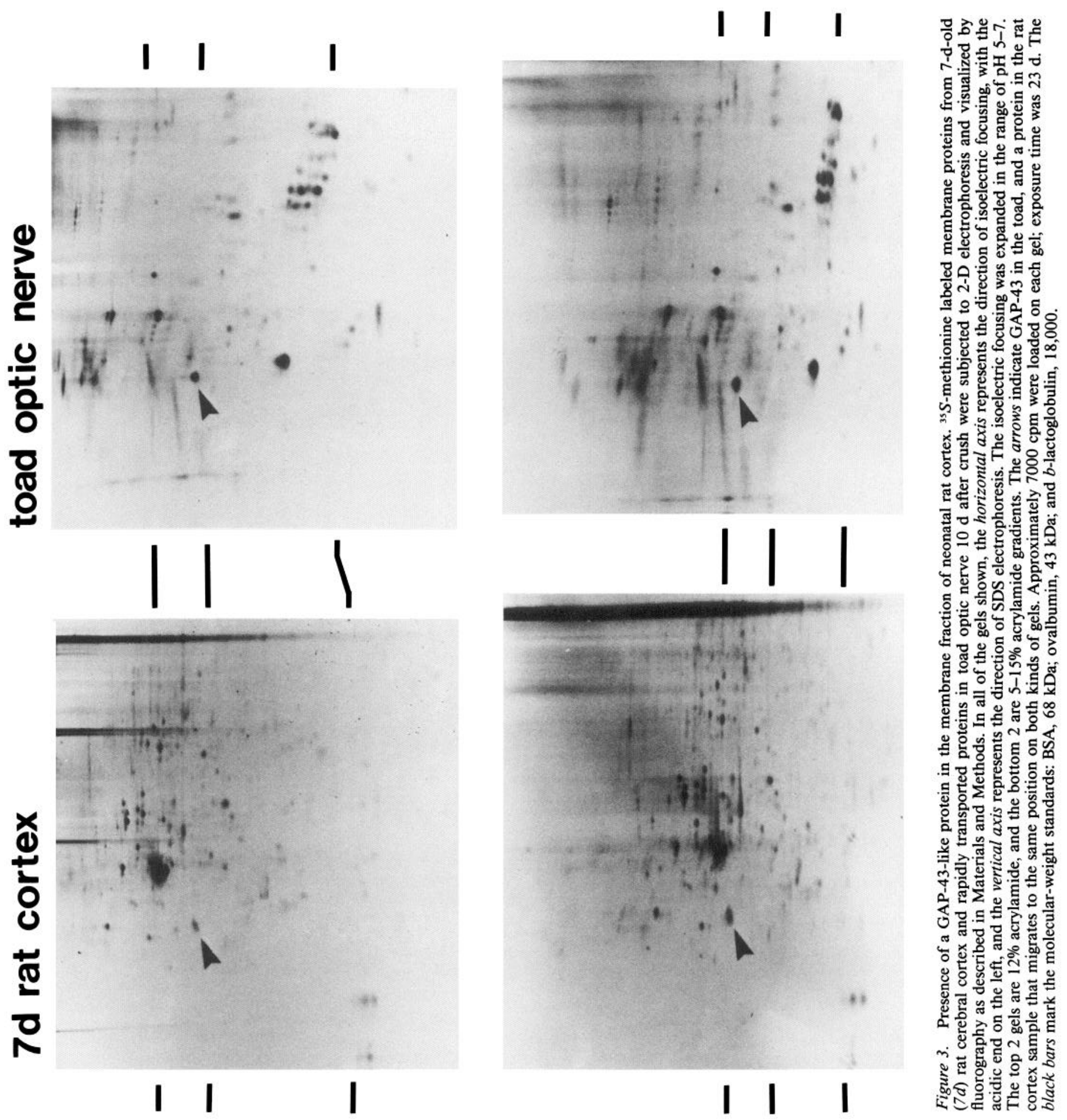

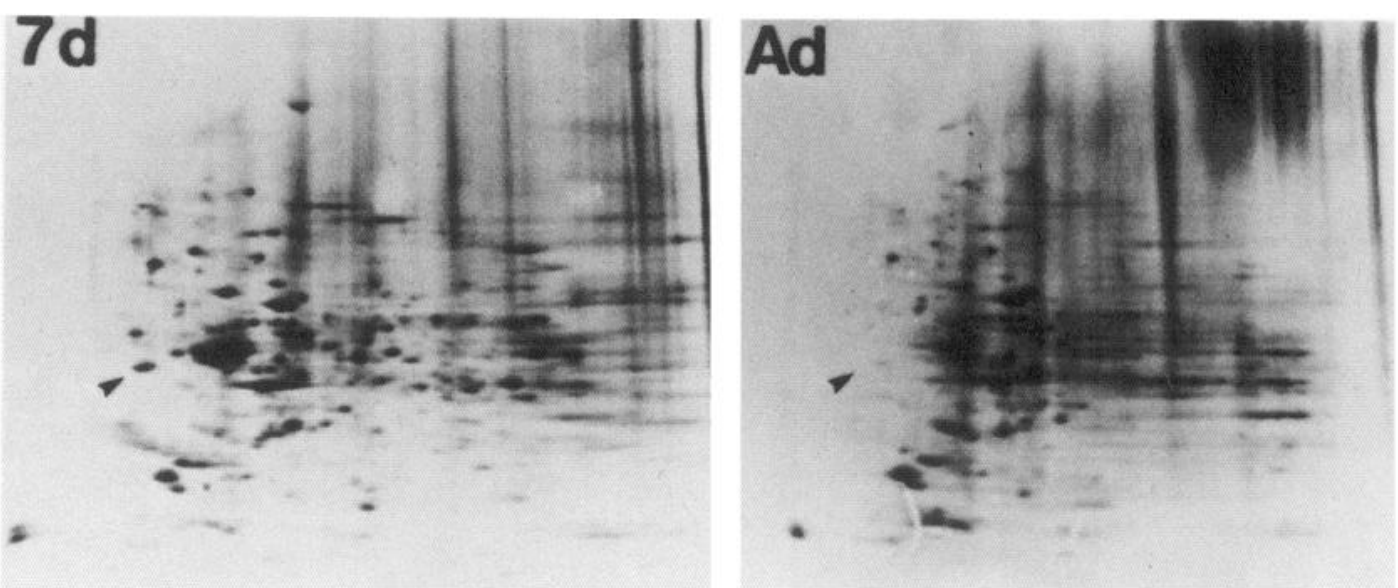

\section{cortex}

AR
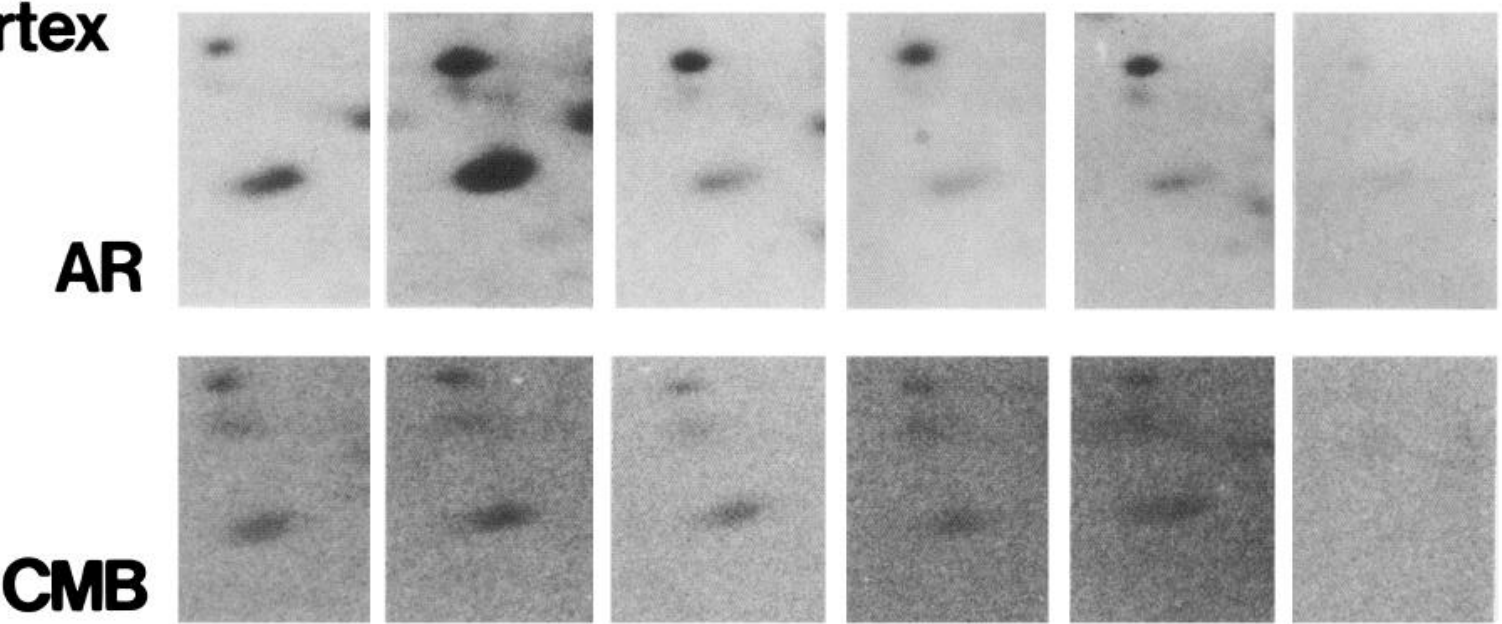

Od

7d

$14 d$

$22 d$

$42 d$

Ad

\section{cerebellum}

\section{AR}
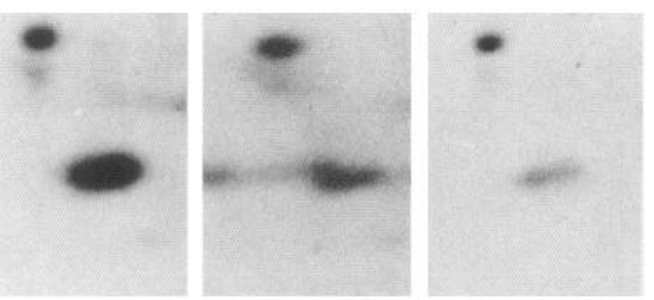
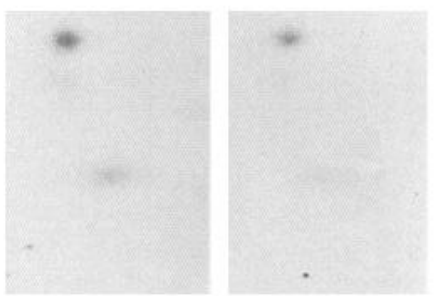

Figure 4. Developmental changes in GAP-43 synthesis in rat brain. The 2 fluorographs at the top are from 2-D gels of 7-d-old (7d) and adult (Ad) rat cerebral cortex membrane proteins. The $\mathrm{pH} \mathrm{4-6}$ range was expanded in isoelectric focusing, and the second (SDS) dimension was run on $5-15 \%$ polyacrylamide gradient gels. $100 \mu \mathrm{g}$ of protein were loaded on each gel; the $7 \mathrm{~d}$ gel was exposed for $260,000 \mathrm{cpm}-\mathrm{d}$ (corrected for decay), and the adult gel was exposed for $350,000 \mathrm{cpm}-\mathrm{d}$, to clearly show the faint GAP-43 spot. Below these whole gels are 3 series of close-ups showing the GAP-43 region by fluorography $(A R)$ and Coomassie staining $(C M B)$. Samples were obtained from neonatal and adult rats on the days indicated. $100 \mu \mathrm{g}$ of protein were loaded per gel in each case, and each exposure was approximately $260,000 \mathrm{cpm}-\mathrm{d}$, with the exception of the $22 \mathrm{~d}(22 \mathrm{~d})$ gels, which for both cortex and cerebellar series were exposed for $220,000 \mathrm{cpm}-\mathrm{d}$.

dance of the specific GAP-43 message, relative to the total mRNA population in the cortex.

Phosphorylation of GAP-43 and similarity to a kinase $C$ substrate, $B-50$

The electrophoretic similarities between mature GAP-43 and the primary translation product suggest that GAP- 43 does not undergo extensive post-translational modifications that would substantially alter its apparent molecular weight or isoelectric point, but our evidence does not exclude all post-translational modification of the protein. Indeed, Katz et al. (1985) have reported that a particulate-fraction protein electrophoretically similar to GAP-43 is among the major substrates for endogenous kinases in isolated growth cones from neonatal rat brains. We have shown that GAP-43 is a major component of these isolated growth cones (J. H. P. Skene, R. D. Jacobson, G. J. Snipes, C. B. McGuire, J. J. Norden, and J. A. Freeman, unpublished observations). When we exposed isolated growth cone membranes to a pulse of ${ }^{32} \mathrm{P}$-ATP in vitro, one of the most heavily labeled proteins exhibited the acrylamide-concentration-dependent molecular-weight shift characteristic of GAP43 (not shown) and comigrated with Coomassie-stained GAP- 
43 upon 2-D electrophoresis (Fig. 7). In vitro phosphorylation of GAP-43 was 4-7-fold greater in growth cone membranes than in synaptic membranes isolated from adult rats (Fig. 8).

The position of GAP-43 on 2-D gels and its phosphorylation in axon terminals are reminiscent of a protein designated "B50" by Gispen and colleagues (Zwiers et al., 1978, 1980). B-50 is a prominent substrate for protein kinase $C$ in synaptic terminals (Aloyo et al., 1983) and appears to influence phosphoinositide metabolism in synaptic membranes (Oestreicher et al., 1983). Recently, B-50 has been found in growth cones from fetal rat brain (de Graan et al., 1985). To test the possibility that the B-50 protein in adult synaptic membranes is the same protein as GAP-43, we partially purified B-50 protein from adult rat brains by the "new procedure" of Oestreicher et al. (1983) through the penultimate step. The final step in the purification of B-50 is preparative IEF. Therefore, authentic B-50 protein is easily identified by $2-D$ electrophoresis of the partially purified material, using analytical scale IEF in the first dimension. Figure 7 shows that the B-50 protein from adult rat brains exactly comigrates with GAP-43 from neonatal rat cortex on 2-D gels. In addition, the apparent molecular weight of the B-50 protein shows the same aberrant dependence on acrylamide concentration as GAP-43 (Table 1 and Oestreicher et al., 1984). Thus the B-50 protein is identical to neonatal cortex GAP-43 in its isoelectric point, apparent molecular weight, aberrant behavior in SDS electrophoresis, and in its localization to membranes of axon terminals.

The antiserum prepared against GAP-43 from neonatal rat brain also recognizes the partially purified B-50 (not shown). This evidence, however, does not rule out the possibility that GAP-43 and B-50 are distinct proteins that comigrate on 2-D gels, because our antigen was purified by preparative electrophoresis. To examine this possibility further, we subjected the anti-GAP-43 antiserum to affinity chromatography with the original antigen preparation. We reasoned that, if $\mathrm{B}-50$ and GAP-43 were different proteins, B-50 would not be expected to be developmentally regulated in the same way as GAP-43. It follows that the "GAP-43" antigen prepared from neonatal brains should contain substantially more GAP-43 than B-50. Immunoaffinity purification with limiting amounts of antigen, then, should yield an antibody fraction proportionately enriched for anti-GAP-43 antibodies. We applied equal amounts of the partially purified B-50 to 2 gel lanes and probed Western blots of these lanes with "preabsorbed" serum (the flow-through from affinity chromatography) and with the affinity-selected antibodies. Figure 9 shows that the preabsorbed antiserum is partially depleted of anti-B-50 antibodies, while the affinity-purified material is enriched for antibodies recognizing the B-50 band. The affinity-purified antiserum also stains the GAP-43 band in samples of neonatal brain (hamster sensorimotor cortex-lane 3; and rat growth cones-lane 4), and the ratio of antibody staining to total protein in this band (determined from Coomassie staining) is similar to that of the B-50 band in the B-50 preparation. Thus, the purified GAP-43 must be selecting relatively similar amounts of anti-B-50 and anti-GAP-43 antibodies. The implication of these observations is that B- 50 is present in the neonatal rat brain in amounts comparable to GAP-43. This further similarity strongly suggests that $\mathrm{B}-50$ and GAP-43 share antigenic determinants and are likely to be the same protein.

\section{Discussion}

\section{Identification of GAP-43}

A prominent developmentally regulated protein expressed throughout neonatal rat brains appears to be a rat homolog of GAP-43 from regenerating toad optic nerves. The rat protein is nearly identical to toad GAP-43 in its migration on 2-D gel electrophoresis, and an antiserum raised against the rat protein cross-reacts with toad GAP-43. Subcellular fractionation shows

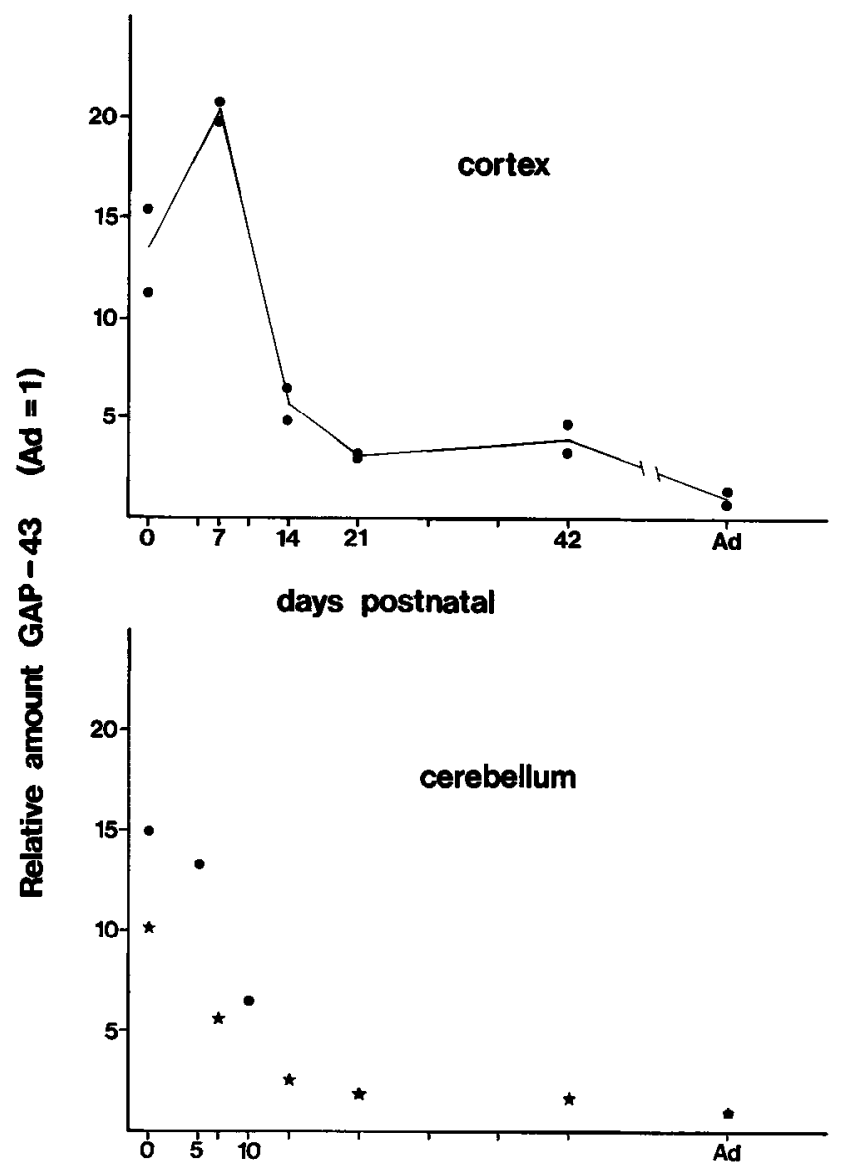

Figure 5. Quantitation of rat GAP-43 synthesis during postnatal development. Fluorograms of $2-D$ gels were scanned with a densitometer using a $0.1 \mathrm{~mm}$ slit whose length encompassed the entire GAP-43 spot. The area under the GAP-43 peak was determined and normalized to the value from the adult $(A d)$ gel. Top, Cortex series; data from two series. Mean of the 2 adult levels set equal to 1 . Bottom, Cerebellar series; data from 2 series ( $\bullet$ and $\star$ ). Adult level from each series set equal to 1 .

that GAP-43 in neonatal rat brain is concentrated primarily in growth cones and immature synaptic terminals (J. H. P. Skene, R. D. Jacobson, G. J. Snipes, C. B. McGuire, J. J. Norden, and J. A. Freeman, unpublished observations), indicating that the rat protein, like toad GAP-43, is an axonally transported neuronal protein.

Toad GAP-43 and the rat protein described here also share a very distinctive aberration in their behavior during SDS gel electrophoresis. The apparent molecular weight of these proteins depends on the acrylamide concentration (increasing apparent molecular weight with decreasing gel concentration). Regardless of the structural basis of this aberration, it is sufficiently unusual among proteins to serve as one criterion for identifying GAP43. The electrophoretic similarities, axonal transport and antigenic cross-reactivity of GAP-43-like proteins from toad, rat, and hamster, strongly suggest that the major structural features of GAP-43 are highly conserved in evolution.

The unusual behavior of GAP-43 on SDS gels confounds our previous estimate of the protein's true molecular weight (Skene and Willard, 1981a). For a different class of proteins with a somewhat similar aberration in SDS gel electrophoresis (glycoproteins), the apparent molecular weight approaches the true molecular weight asymptotically with increasing gel concentration (Banker and Cotman, 1972; Segrest and Jackson, 1972). We do not think GAP-43's aberrant gel migration is due to glycosylation, because the putative primary translation product 

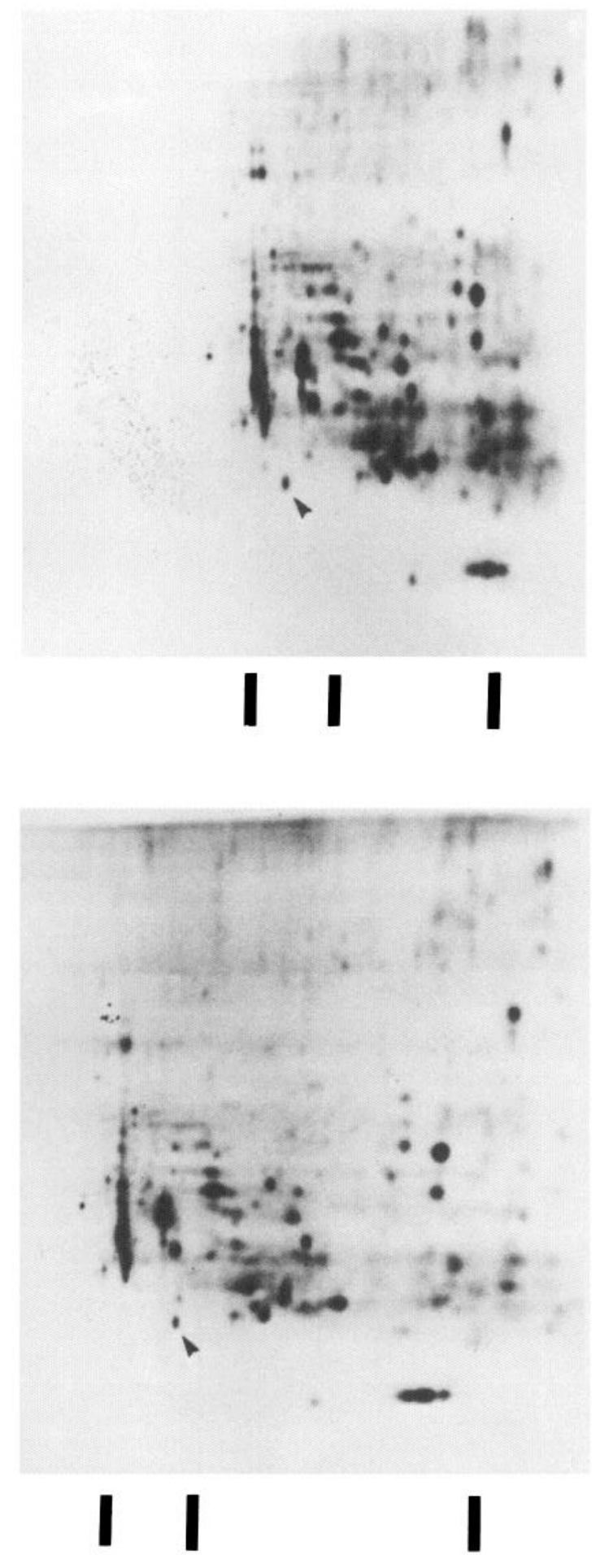
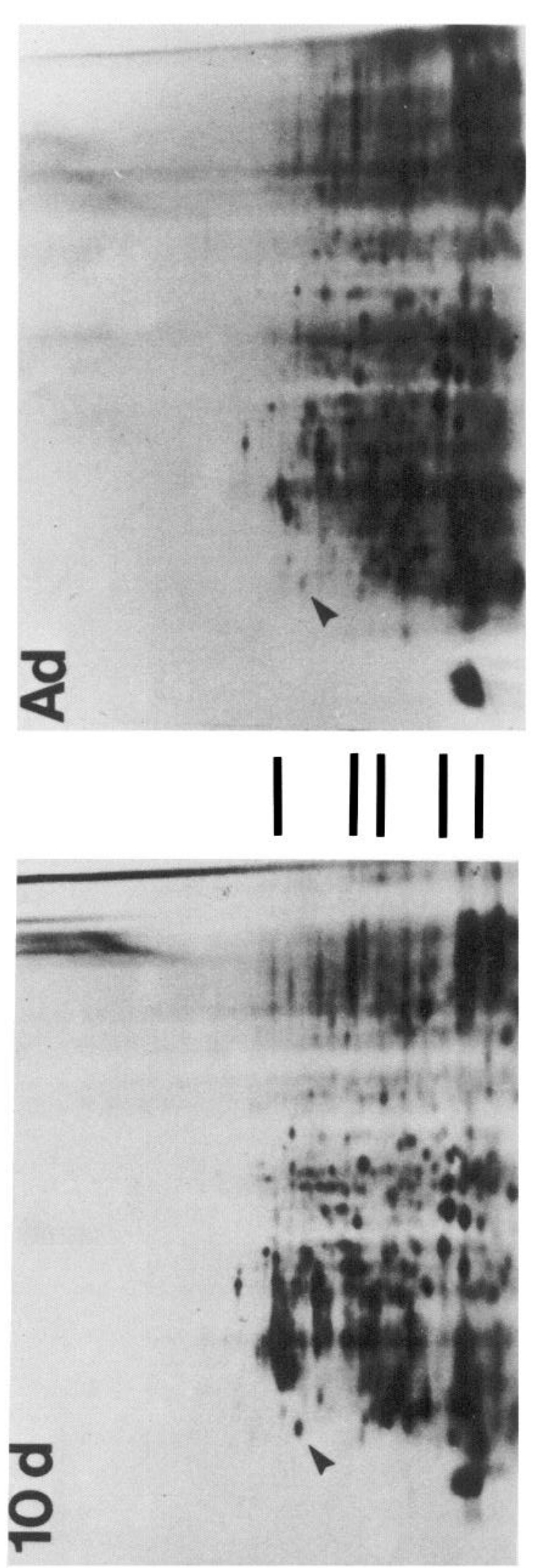

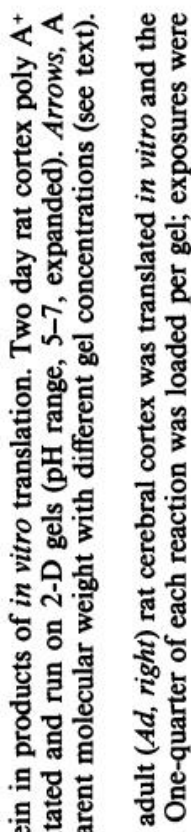

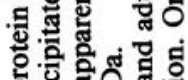
a 舟舟 किण to

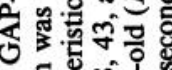
of

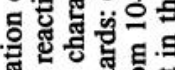
过 의 呵

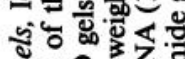
हैं

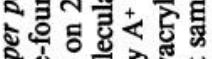

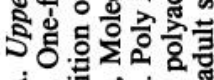

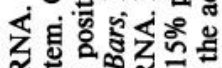

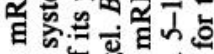
\%

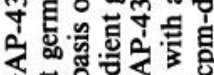

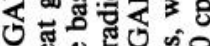
论

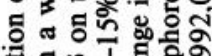

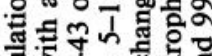
政

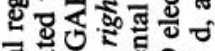

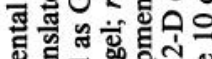

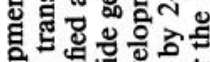
ô의

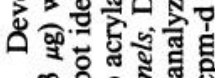
$\rightarrow 3$

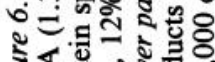

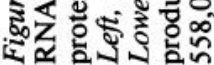



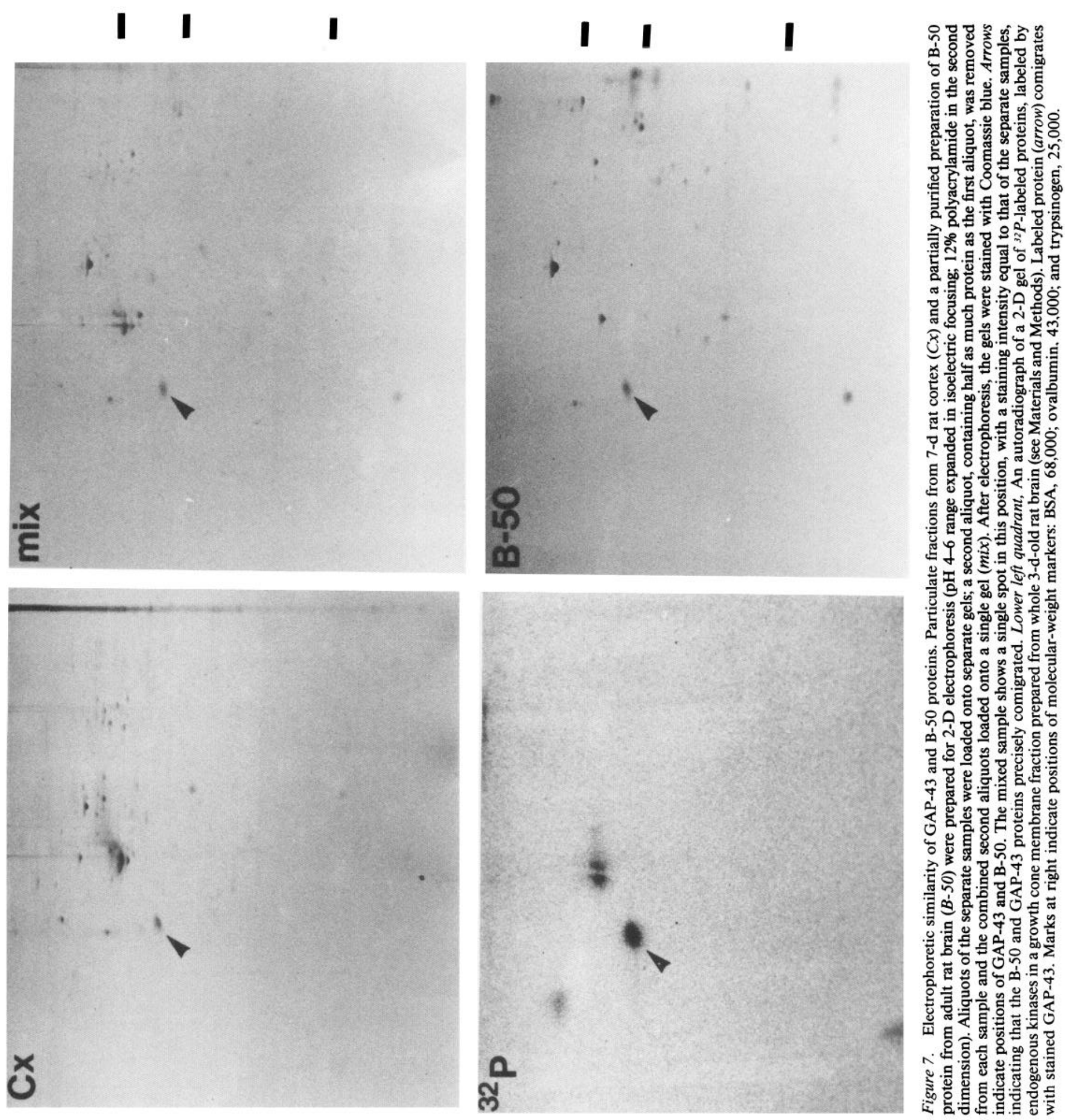


\section{GC $\mid$ Syn.}

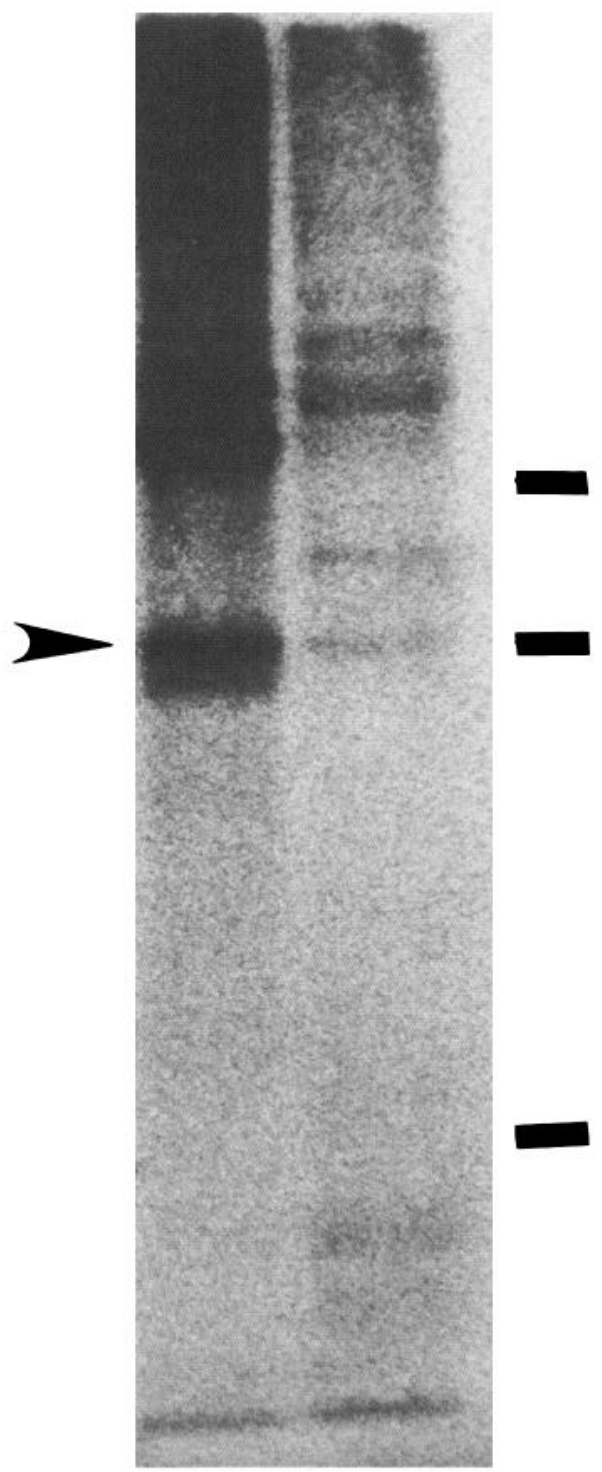

Figure 8. Comparison of GAP-43 phosphorylation in growth cone $(G C)$ and mature synaptic (Syn) membranes. Growth cone membranes from 3-d-old rats and synaptic membranes from adult rats were prepared as described in Materials and Methods, and incubated with ${ }^{32} \mathrm{P}-\mathrm{ATP}$ for $3 \mathrm{~min}$. The labeled proteins were separated by SDS/urea electrophoresis on a gel containing $12 \%$ polyacrylamide and $8 \mathrm{M}$ urea, $\mathrm{pH} 9.3$. Arrow, The position of GAP-43. Bars, The positions of molecularweight markers: BSA, 68,000; ovalbumin, 43,000; and trypsinogen, 25,000

shows similar behavior. Nevertheless, the aberrant electrophoretic behavior of GAP-43 might be explained by resistance to SDS denaturation, as in the case of glycoproteins. This would suggest that the true molecular weight of GAP-43 is in the vicinity of $40-45,000$, as indicated by its relative mobility on high-percentage acrylamide gels. Our original estimate of the protein's molecular weight $(43,000)$ was made using high-percentage acrylamide SDS gels containing $8 \mathrm{~m}$ urea, where the dependence of the protein's apparent molecular weight on acrylamide concentration is less pronounced. To avoid introducing additional names for an already polynominous protein, we will continue for now to use the designation "GAP-43," with

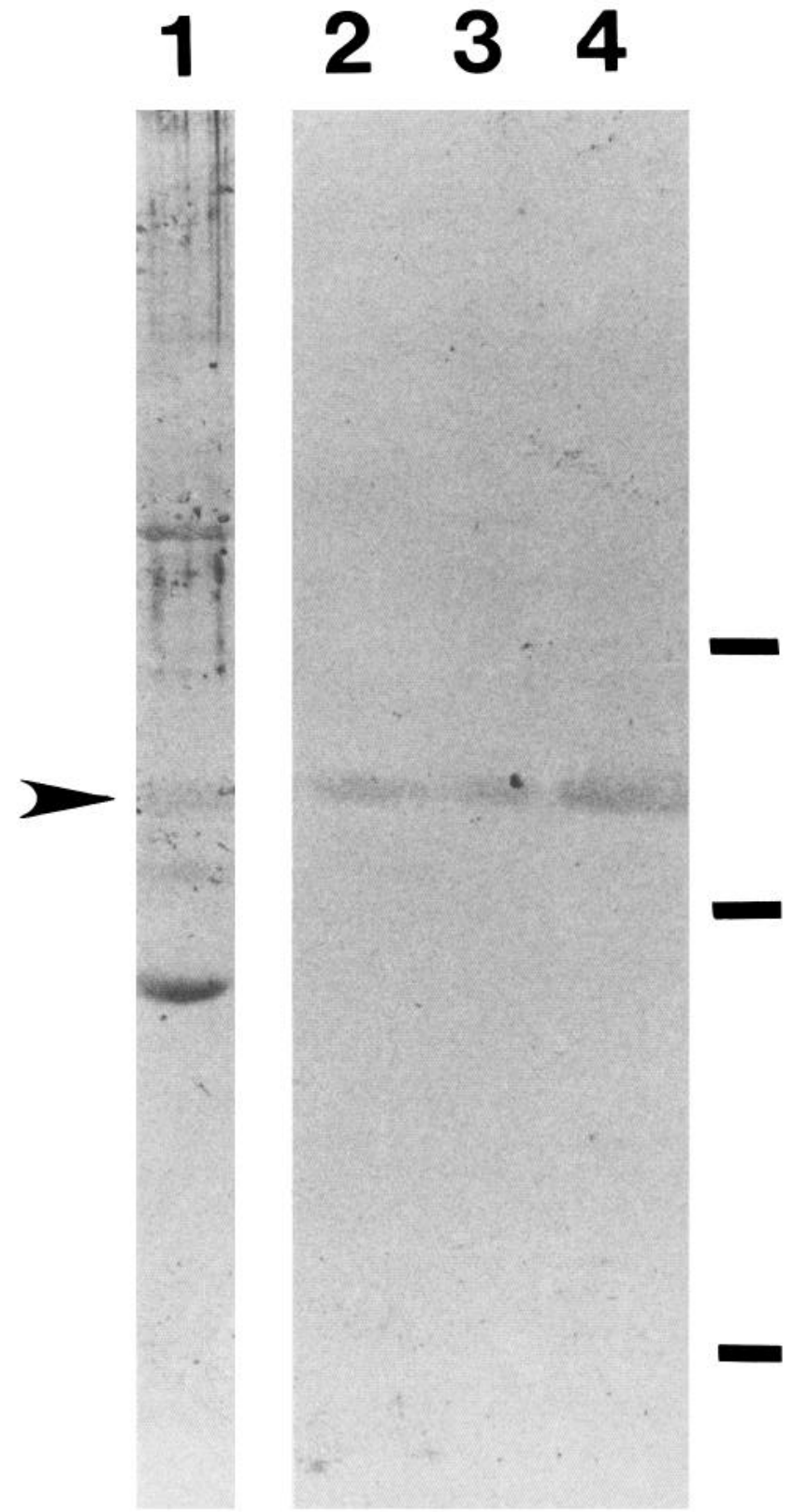

Figure 9. Immunological similarity of GAP-43 and B-50 proteins. Western blots of partially purified B-50 protein (lanes 1 and 2), 12-dold hamster somatomotor cortex (lane 3), and growth cone membranes from 3-d-old rats (lane 4) were immunostained with the flowthrough (preabsorbed) serum from a "GAP-43" affinity column (lane I) or with the affinity-purified antibodies (lanes 2-4). Electrophoresis was on $10 \%$ polyacrylamide gels. The preabsorbed serum is partially depleted of, and the affinity-selected material enriched for, antibodies that stain the B-50 band (arrow). The relative intensity of immunostaining of the B50 , hamster, and rat growth cone samples is proportional to the total amount of GAP-43 plus B-50 (determined by Coomassie staining of the GAP-43/B-50 spot on 2-D gels), indicating that the antibody is not recognizing simply a small amount of contaminating GAP-43 in the B50 preparation. Bars, The positions of molecular-weight markers: BSA, 68,000; ovalbumin, 43,000; and trypsinogen, 25,000 .

the caution that the protein's true molecular weight remains to be established.

GAP-43's aberrant electrophoretic behavior is important for our purposes in that it permits us to confirm the identity of GAP-43 in a variety of circumstances. For example, Szaro et al. (1985) have studied the changes in axonally transported pro- 
teins during regeneration of the optic nerve in Xenopus, and did not find any protein homologous to GAP-43 in their rapid transport group. However, inspection of their 2-D gel fluorographs reveals an acidic protein with an apparent molecular weight of $56 \mathrm{kDa}$ on a gradient poured from 4 and $17 \%$ solutions, which they have labeled No. 23. This protein is rapidly transported and substantially increased during regeneration. We believe that it may be the homolog of GAP-43 in Xenopus. This observation points out the importance of analyzing proteins of interest in a variety of gel systems.

The apparent molecular-weight shift has also permitted us to infer the presence of GAP-43 in primary translation products of rat cortex mRNA. We further infer that GAP-43 is not posttranslationally modified to an extent that its electrophoretic properties are noticeably altered. This argues against the possibility that decline in GAP-43 in the adult is due to a modification that moves it to another part of the gel.

The in vitro translations also indicate that the difference between neonate and adult with respect to GAP-43 synthesis is mirrored in the relative amount of specific GAP-43 message in the poly $\mathrm{A}^{+}$RNA pool. Our quantitation of GAP-43 mRNA in neonatal and adult rat cortex, and comparison with the developmental decline in in vivo synthesis of the protein, indicates that developmental regulation of GAP-43 synthesis is mediated largely at the level of mRNA abundance. Our quantitative estimates of $\mathrm{mRNA}$ abundance, however, are not precise enough to rule out additional regulation at the level of translational efficiency or sequestration in the large poly $\mathrm{A}^{-}$fraction found in adult brain RNA (Chaudhari and Hahn, 1983). More precise information about the level(s) of GAP-43 regulation can be obtained using specific cDNA probes for GAP-43 mRNA. Evidence for differential abundance of GAP-43 mRNA in neonatal and adult brains, and identification of a putative cell-free translation product, should provide the basis for isolation of an appropriate cDNA clone.

\section{Correlation with axon growth}

The rat brain protein that we have identified with toad GAP43 is prominent among the newly synthesized proteins in several regions of the developing CNS, and Coomassie staining (a measure of steady-state abundance) shows that it is among the most abundant proteins in the brain during this period. This suggests that many different neurons synthesize GAP-43 during development. The marked decline in GAP-43 synthesis and abundance during maturation-apparent in all of the CNS regions we studied-indicates that GAP-43 is developmentally regulated in most neurons. The widespread occurrence of GAP-43 suggests that the protein participates in an activity common to all or most neurons, and its selective enhancement during development is consistent with a role in axon growth.

Participation of GAP-43 in axon growth is also suggested by subcellular localization of the protein. GAP-43 is a remarkably abundant component of growth cone membranes isolated from fetal and neonatal brains (Fig. 9; de Graan et al., 1985; J. H. P. Skene, R. D Jacobson, G. J. Snipes, C. B. McGuire, J. J. Norden, and J. A. Freeman, unpublished observations). Immature synaptosomes contain somewhat less GAP-43, and the small amount of GAP-43 in adult rat brains is concentrated in synaptic membranes. Immunohistochemical localization at the light-microscopic level (McGuire et al., 1985; Skene et al., unpublished observations) shows high levels of GAP-43 immunoreactivity in areas known to contain growth cones and immature synapses. We conclude that, like its homolog in regenerating toad neurons, GAP-43 in developing rat brain is a neuronal protein that is axonally transported and accumulates at the terminals of both growing axons and axons that have formed synaptic connections.

Because we have examined very large CNS regions, containing many different classes of neurons, we cannot precisely correlate the timing of GAP-43 synthesis with axon growth during development. Nevertheless, maximal GAP-43 synthesis does correspond roughly to periods of profuse axon outgrowth and synaptogenesis. In the cerebral cortex, GAP-43 synthesis follows a broad time course, peaking early in the second postnatal week. During the first and second weeks of postnatal life, there is extensive elongation of callosal axons, which pause and then reinitiate growth into deeper cortical layers (along with thalamocortical and association axons; Valentino and Jones, 1982). Elongation of corticospinal axons also continues through the second postnatal week (Schreyer and Jones, 1982). In the cerebellum, GAP-43 synthesis is most prominent during the first postnatal week and then declines to about twice the adult level at 3 weeks. During this early phase of postnatal development, granule cell precursors in the premigratory layer are extending processes that will eventually become the parallel fibers of the molccular laycr (Altman, 1972a, b, c). The decrease in GAP43 synthesis occurs at a time when fiber growth is still occurring, e.g., continued parallel fiber growth, outgrowth of Purkinje cell axons along with those of other intrinsic cerebellar neurons, and ingrowth of afferents. This decline may reflect the proliferation of other elements, such as neuronal and glial cell bodies and dendritic processes, relative to the bulk of growing axons. The time course of GAP-43 synthesis in the cerebellum is similar to that shown by the microtubule-associated protein MAP1; this pattern is the basis for the argument that MAP1 may play a particularly important role in axon growth (Calvert and Anderton, 1985). The appearance of high levels of GAP-43 immunoreactivity in dentate gyrus and superior colliculus also corresponds to times of exuberant axon ingrowth (McGuire et al., 1985). Thus, at the crude level of temporal resolution possible for large brain regions studied as a whole, maximal expression of GAP-43 is correlated with periods of axonal growth.

\section{"Residual" GAP-43 in the mature CNS}

The presence of significant amounts of GAP-43 in mature neurons is not predicted by the hypothesis that GAP-43 is a simple $\mathrm{ON} / \mathrm{OFF}$ regulator of axon growth, and any complete explanation of the protein's role in neuronal life must take into account this "residual" GAP-43. It may be that the residual GAP43 in mature brains is distributed homogeneously among synapses, each synapse in the brain containing the same small concentration of GAP-43 as any other synapse. In that case, we would expect that a low level of GAP-43 activity (whatever that activity might be) contributes to some aspect of normal synaptic function, while a greatly elevated level of GAP-43 activity might subserve some step(s) in axon growth. An alternative possibility is that the residual GAP-43 in mature brains is distributed heterogeneously among different neurons. In an extreme case, one can envision a minority of neurons synthesizing GAP-43 and accumulating the protein in their axon terminals at levels similar to growth cones, while the majority of neurons contain little or no GAP-43. The population of "high-GAP-43" neurons might comprise a discrete set of neurons that synthesize GAP-43 at high levels throughout life; or the "high-GAP-43" population might represent the set of neurons in which GAP-43 synthesis has been activated transiently at the time of sampling. In either case, we would expect the neurons with high levels of GAP-43 to be more susceptible to axon sprouting or synaptic plasticity.

The "residual" GAP-43 in mature brains is particularly interesting in light of the proposed identity of GAP-43 with B-50. B-50 was first described in the adult rat brain and was selected as a particularly interesting protein because modulation of its phosphorylation by ACTH corresponded closely to the effects of ACTH on learning (Zwiers et al., 1978, 1980). Phosphorylation of an apparently identical protein $(\mathrm{F} 1)$ has been related to long-term potentiation in the rat hippocampus (Nelson and Routtenberg, 1985; Nelson et al., 1985), a phenomenon often taken as a model of learning and memory. The correlations 
between $\mathrm{B}-50 / \mathrm{F} 1$ phosphorylation and effects on memory suggest that the function of GAP-43/B-50/F1 is related to synaptic plasticity. Synaptic plasticity comprises a spectrum of cellular events - from changes in the coupling of depolarization to neurotransmitter release, to synaptic and axonal sprouting, to actual fiber outgrowth - many of which share requirements for changes in cytoskeletal and membrane organization. It is therefore tempting to speculate that GAP-43 mediates some event(s) common to many components of plasticity.

The influence of GAP-43 on axon terminals is potentially regulated at 2 levels. First, changes in the abundance of GAP43 can be brought about by changes in mRNA levels in the cell body. Changes in GAP-43 synthesis in development and regeneration appear to occur with a time course in the range of days to weeks. Second, the specific activity of the protein might be regulated in response to local conditions via endogenous GAP43 kinase(s). Experiments with B-50 and F1 in synaptic membranes have suggested that the residual GAP-43 in synaptic terminals represents a pool of the protein that can be activated by phosphorylation in response to short-term stimuli. Our experiments and the more detailed study by Katz et al. (1985) suggest that GAP -43 may be much more highly phosphorylated in growth cones than in mature synapses. Katz et al. reported a much higher rate of in vitro phosphorylation of an acidic, 46 $\mathrm{K}$ protein in a particulate fraction growth cones than in a comparable synaptic fraction. A recent report (Nelson et al., 1985) indicates that this pp46 is identical to protein $F 1$, and that the protein can be phosphorylated by both calcium/calmodulindependent kinase and kinase $\mathrm{C}$. We have no evidence indicating whether the higher rate of GAP-43 phosphorylation in growth cones represents constitutive activation of a kinase, or whether the kinase(s) can be regulated by interactions of the growth cone with its environment (Berridge and Irvine, 1984; Nishizuka, 1984). Kinase $C$ has been detected in significant amounts in the developing brain, using ${ }^{3} \mathrm{H}$-phorbol ester binding (Nagle et al., 1981), and its distribution is suggestive of a presence in differentiating, rather than proliferating, neural tissue (Murphy et al., 1983). It is likely that phosphorylation of GAP-43 regulates the protein's activity, either by activating the inactive unphosphorylated protein or by modifying the substrate or binding specificities of the protein. In either event, the level of growthrelated GAP-43 activity would be regulated synergistically by regulation of GAP- 43 synthesis in the cell body and local control of physphorylation at axon terminals.

\section{Implications for $C N S$ regeneration}

Although the small pool of GAP-43 in mature synaptic terminals might be activated under appropriate conditions to permit various elements of plasticity, this pool of GAP-43 is not available in the case of axon injury. Physical interruption of an axon by trauma or disease deprives the proximal axon stump of the synaptic bolus of GAP-43. A net increase in GAP-43 to replace the lost bolus and elevate the protein to the level typical of growth cones (J. H. P. Skene, R. D. Jacobson, G. J. Snipes, C. B. McGuire, J. J. Norden, and J. A. Freeman, unpublished observations) would require either increased synthesis of GAP43 or a decrease in the protein's degradation. Since turnover of GAP-43 in mature neurons appears to occur on the order of weeks (Fig. 4), changes in protein degradation alone could not cause rapid increases in GAP-43 abundance. If degradation of GAP-43 in injured axons continued at least at the low level typical of uninjured neurons, then no net increase in the protein could occur without increased GAP-43 synthesis. In contrast to successfully regenerating systems, the mammalian CNS neurons examined so far fail to increase GAP-43 synthesis after axotomy (Kalil and Skene, in press; Skene and Willard, 1981b). "Growth cones" formed by these injured axons therefore may be deficient in at least one major membrane protein, which might limit the axons' ability to regenerate.

\section{References}

Aloyo, V. J., H. Zwiers, and W. H. Gispen (1983) Phosphorylation of B-50 protein by calcium-activated, phospholipid-dependent protein kinase and B-50 protein kinase. J. Neurochem. 41: 649-653.

Altman, J. (1972a) Postnatal development of the cerebellar cortex in the rat $\mathrm{I}$. The external germinal layer and the transitional molecular layer. J. Comp. Neurol. 145: 353-398.

Altman, J. (1972b) Postnatal development of the cerebellar cortex in the rat II. Phases in the maturation of Purkinje cells and of the molecular layer. J. Comp. Neurol. 145: 399-464.

Altman, J. (1972c) Postnatal development of the cerebellar cortex in the rat III. Maturation of the components of the granular layer. J. Comp. Neurol. 145: 465-514.

Aviv, H., and P. Leder (1972) Purification of biologically active globin messenger RNA by chromatography on oligothymidylic acid-cellulose. Proc. Natl. Acad. Sci. USA 69: 1408-1411.

Banker, G. A., and C. M. Cotman (1972) Measurement of free electrophoretic mobility and retardation coefficient of protein-sodium dodecyl sulfate complexes by gel electrophoresis. J. Biol. Chem. 247 . 5856-5861.

Benfey, M., and A. J. Aguayo (1982) Extensive elongation of axons from rat brain into peripheral nerve grafts. Nature 296: 150-152.

Benowitz, L. I., and E. R. Lewis (1983) Increased transport of 44,000to 49,000 -dalton acidic proteins during regeneration of the goldfish optic nerve: A two-dimensional gel analysis. J. Neurosci. 3: 21532163.

Benowitz, L. I., V. E. Shashoua, and M. G. Yoon (1981) Specific changes in rapidly transported proteins during regeneration of the goldfish optic nerve. J. Neurosci. $1:$ 300-307.

Berridge, M. J., and R. F. Irvine (1984) Inositol triphosphate, a novel second messenger in cellular signal transduction. Nature $312: 315$ 321.

Bishop, J. M. (1985) Viral oncogenes. Cell 42: 23-38.

Calvert, R., and B. H. Anderton (1985) A microtubule-associated protein (MAP1) which is expressed at elevated levels during development of the rat cerebellum. EMBO J. 4: 1171-1176.

Chaudhari, N., and W. E. Hahn (1983) Genetic expression in the developing brain. Science 220:924-928.

Chirgwin, J. M., A. E. Przybyla, R. J. MacDonald, and W. J. Rutter (1979) Isolation of biologically active ribonucleic acid from sources enriched in ribonuclease. Biochemistry 18: 5294-5299.

Cohen, R. S., F. Blomberg, K. Berzins, and P. Siekevitz (1977) The structure of postsynaptic densities isolated from dog cerebral cortex. I. Overall morphology and composition. J. Cell Biol. 74: 181-203.

de Graan, P. N. E., C. O. M. van Hooff, B. C. Tilly, A. B. Oestreicher P. Schotman, and W. H. Gispen (1985) Phosphoprotein B-50 in nerve growth cones from fetal rat brain. Neurosci. Lett. $61: 235-241$.

Fairbanks, G., T. L. Steck, and D. F. H. Wallach (1971) Electrophoretic analysis of the major polypeptides of the human erythrocyte membrane. Biochemistry 10: 2606-2617.

Fallon, J. R. (1985) Preferential outgrowth of central nervous system neurites on astrocytes and Schwann cells as compared to nonglial cells in vitro. J. Cell Biol. 100: 198-207.

Heacock, A. M., and B. W. Agranoff (1982) Protein synthesis and transport in the regenerating goldfish visual system. Neurochem. Res. 7: $771-788$.

Jen, G., and R. E. Thach (1982) Inhibition of host translation in encephalomyocarditis virus-infected L cells: A novel mechanism. J. Virol. 43: 250-261.

Kalil, K., and J. H. P. Skene. (in press) Failure of regeneration in mammalian CNS correlates with developmental decline in an axonal protein. J. Neurosci.

Katz, F., L. Ellis, and K. H. Pfenninger (1985) Nerve growth cones isolated from fetal rat brain. III. Calcium-dependent protein phosphorylation. J. Neurosci. 5: 1402-1411.

Laemmli, U. K. (1970) Cleavage of structural proteins during the assembly of the head of bacteriophage T4. Nature 227: 680-685.

Laskey, R. A., and A. D. Mills (1975) Quantitative film detection of ${ }^{3} \mathrm{H}$ and ${ }^{14} \mathrm{C}$ in polyacrylamide gels by fluorography. Eur. J. Biochem. 56: $335-341$

LeTourneau, P. C. (1975) Cell-to-substratum adhesion and guidance of axonal elongation. Dev. Biol. 44: 92-101.

Lowry, O. H., N. J. Rosebrough, A. L. Farr, and R. J. Randall (1951) Protein measurement with the Folin phenol reagent. J. Biol. Chem. 193: $265-275$

Malik, N., and A. Berrie (1972) New stain fixative for proteins sep- 
arated by gel isoelectric focusing based on Coomassie Brilliant Blue. Anal. Biochem. 49: 173-176.

McGuire, C. B., J. J. Norden, S. Bock, and J. A. Freeman (1985) Immunohistochemical localization of a neuronal growth-associated protein (GAP-43) in neonatal rat brain. Soc. Neurosci. Abstr. 11:419.

Morrisey, J. H. (1981) Silver stain for proteins in polyacrylamide gels: A modified procedure with enhanced uniform sensitivity. Anal. Biochem. 117: 307-310.

Murphy, K. M. M., R. J. Gould, M. L. Oster-Granite, J. D. Gearhart, and S. H. Snyder (1983) Phorbol ester receptors: Autoradiographic identification in the developing rat. Science 222: 1036-1038.

Nagle, D. S., S. Jake, M. Castagna, and P. M. Blumberg (1981) Variation with embryonic development and regional localization of specific $\left({ }^{3} \mathrm{H}\right)$-phorbol 12,13-dibutyrate binding to brain. Cancer Res. 41 : 89-93.

Nelson, R. B., and A. Routtenberg (1985) Characterization of protein F1 (47kDa, $4.5 \mathrm{pI}$ ): A kinase C substrate directly related to neural plasticity. Exp. Neurol. 89: 213-224.

Nelson, R. B., A. Routtenberg, C. Hyman, and K. H. Pfenninger (1985) A phosphoprotein (F1) directly related to neural plasticity in adult rat brain may be identical to a major growth cone protein (pp46). Soc. Neurosci. Abstr. 11: 927.

Nishizuka, Y. (1984) The role of protein kinase $C$ in cell surface signal transduction and tumour promotion. Nature 308: 693-698.

Oestreicher, A. B., D. J. van Dongen, H. Zwiers, and W. H. Gispen (1983) Affinity-purified anti-B-50 antibody: Interference with the function of the phosphoprotein B-50 in synaptic plasma membranes. J. Neurochem. 41: 331-340.

Oestreicher, A. B., M. van Duin, H. Zwiers, and W. H. Gispen (1984) Cross-reaction of anti-rat B-50: Characterization and isolation of a "B-50 phosphoprotein" from bovine brain. J. Neurochem. 43: 935943.

O'Farrell, P. H. (1975) High resolution two-dimensional electrophoresis of proteins. J. Biol. Chem. 250: 4007-4021.

Parikh, I., S. March, and P. Cuatrecasas (1974) Topics in the methodology of substitution reactions with agarose. Methods Enzymol. 34: 77-102.

Pfenninger, K. H., L. Ellis, M. P. Johnson, L. B. Friedman, and S. Somlo (1983) Nerve growth cones isolated from fetal rat brain: Subcellular fractionation and characterization. Cell 35: 573-584.

Richardson, P. M., V. M. K. Issa, and A. J. Aguayo (1984) Regeneration of long spinal axons in the rat. J. Neurocytol. 13: 165-182.
Rogers, S. L., J. B. McCarthy, S. L. Palm, L. T. Furcht, and P. C. LeTourneau (1985) Neuron-specific interactions with two neuritepromoting fragments of fibronectin. J. Neurosci. 5: 369-378.

Sanes, J. R. (1985) Laminin for axonal guidance? Nature 315: 714715.

Schreyer, D. J., and E. G. Jones (1982) Growth and target finding by axons of the corticospinal tract in prenatal and postnatal rats. Neuroscience 7: 1837-1853.

Segrest, J. P., and R. L. Jackson (1972) Molecular weight determination of glycoproteins by polyacrylamide gel electrophoresis in sodium dodecyl sulfate. Methods Enzymol. 28: 54-63.

Skene, J. H. P., and M. Willard (1981a) Changes in axonally transported proteins during regeneration in toad retinal ganglion cells. $J$. Cell Biol. 89: 86-95.

Skene, J. H. P., and M. Willard (1981b) Axonally transported proteins associated with growth in rabbit central and peripheral nervous system. J. Cell Biol. 89: 96-103.

Skene, J. H. P., R. D. Jacobson, G. J. Snipes, C. B. McGuire, J. J. Norden, and J. A. Freeman (1986) A protein induced during nerve regeneration (GAP-43) is a major component of growth cone membranes.

Szaro, B. G., Y. P. Loh, and R. K. Hunt (1985) Specific changes in axonally transported proteins during regeneration of the frog (Xenopus laevis) optic nerve. J. Neurosci. 5: 1402-1411.

Ueda, T., P. Greengard, K. Berzins, R. S. Cohen, F. Blomberg, D. J. Grab, and P. Siekevitz (1979) Subcellular distribution in cerebral cortex of two proteins phosphorylated by cAMP-dependent protein kinase. J. Cell Biol. 83: 308-319.

Valentino, K. L., and E. G. Jones (1982) The early formation of the corpus callosum: A light and electron microscopic study in foetal and neonatal rats. J. Neurocytol. 11: 583-609.

Weinberg, R. A. (1985) The action of oncogenes in the cytoplasm and nucleus. Science 230: 770-776.

Zwiers, H., V. M. Weigant, P. Schotman, and W. H. Gispen (1978) ACTH induced inhibition of endogenous rat brain protein phosphorylation in vitro: Structure-activity. Neurochem. Res. 3: 455-463.

Zwiers, H., P. Schotman, and W. H. Gispen. (1980) Purification and some characteristics of ACTH-sensitive protein kinase and its substrate protein in rat brain membranes. J. Neurochem. 34: 1689-1699. 